\title{
GEOINFORMATION TECHNOLOGIES FOR GEOECOLOGICAL MONITORING OF URBANIZED WATER BODIES
}

\author{
Yue Zheng ${ }^{1}$, Sheviakina N.A. ${ }^{2}$, Zagorodnia S.A. ${ }^{2}$, Kreta D.L. ${ }^{2}$, Radchuk I.V. ${ }^{2}$ \\ ${ }^{1}$ Yancheng Polytechnic College \\ № 285, Jiefang Rd. Yandu District, Yancheng, 224006, Jiangsu Province, China \\ ${ }^{2}$ Institute of Telecommunications and Global Information Space National Academy \\ of Sciences of Ukraine \\ 13, Chokolovskiy blv., 03186, Kyiv \\ n.a.sheviakina@gmail.com; zagorodnya.s@gmail.com; \\ dim.leo@gmail.com; 523180183@qq.com, igor.radchuk.v@gmail.com
}

\begin{abstract}
The study of the state of urbanized aquatic ecosystems is necessary to study the regularities of the functioning of water resources under a stable anthropogenic load. The article analyzes the distribution of biotopes in the urbanized coastal area of the Lake Verbne (Kyiv). The study was carried out on the basis of remote sensing data in order to determine informative signs of the ecological state of the territory and the natural resource potential for recreational purposes. An algorithm for building a map of the distribution of biotopes of the territory is presented. The article presents topical thematic ecological-cartographic models. An assessment and analysis of the ecological state of the coastal area using geoinformation technologies has been carried out. It is concluded that the direct anthropogenic impact exerts an increased recreational load on the coastal area of the lake. Areas of the coastal territory with a vegetation cover are a place of mass gathering of vacationers. As a result of trampling, degradation of plant complexes is noted until the complete disappearance of groups and succession processes are noted. Therefore, it is necessary to regulate unauthorized recreational development of the area around Lake Verbne (Kyiv). The effectiveness of Earth remote sensing methods for monitoring studies on the distribution of biotopes, determination of the ecological state and quality of the recreational potential of urbanized water bodies of cities has been proved. The presented studies are necessary to stabilize the ecological balance of urban agglomerations, improve the quality of ecological services in urban landscapes, improve the state of the environment for comfortable living of the city population and ensure the ecological safety of urbanized coastal areas and lakes. Key words: geoecological monitoring, geoinformation systems, remote sensing of the Earth, water bodies, urbanized water bodies, anthropogenic impact, complex analysis.
\end{abstract}

Геоінформаційні технології геоекологічного моніторингу урбанізованих водних об’єктів. Юе Чжен, Шевякіна Н.А., Загородня С.А., Крета Д.Л., Радчук І.В.

Дослідження стану урбанізованих водних екосистем $€$ необхідним для вивчення закономірностей функціонування водних ресурсів за стійкого антропогенного навантаження. У статті проаналізовано розподіл біотопів на урбанізованій прибережній території о. Вербне (м. Києв) за результатами Д33 із метою визначення інформативних ознак екологічного стану території і природно-ресурсного потенціалу для рекреаційних цілей. Представлено алгоритм побудови карти розподілу біотопів території. Побудовано актуальні тематичні еколого-картографічні моделі. Карти класифікації біотопів у весняно-літній період отримували протягом чотирьох років (20217-2020рр.). Проведено оцінку й аналіз екологічного стану прибережної території із застосуванням геоінформаційних технологій. Для розрахунків площі біотопів була використана частина водоохоронної зони озера завширшки 100 метрів. Зроблено висновок, що загалом досліджувана лімноекосистема є стабільною з поступовими змінами та сукцесійними процесами. Водночас прибережна територія озера піддається посиленому рекреаційному навантаженню внаслідок прямого антропогенного впливу. На ділянках із рослинним покривом відмічено масове скупчення відпочиваючих. Унаслідок витоптування відбувається деградація рослинних комплексів, що супроводжується сукцесійними процесами. Тому необхідним $є$ регулювання несанкціонованого рекреаційного облаштування території навколо озера Вербне. Доведено ефективність методів дистанційного зондування Землі для моніторингових досліджень за розподілом біотопів, визначення екологічного стану та якості рекреаційного потенціалу урбанізованих водних об’єктів міст. Представлені дослідження необхідні для стабілізації екологічної рівноваги міських агломерацій, підвищення продуктивності міських ландшафтів, поліпшення стану довкілля і забезпечення екологічної безпеки урбанізованих прибережних територій та озер. Ключові слова: геоекологічний моніторинг, геоінформаційні системи, дистанційне зондування Землі, водні об'єкти, урбанізовані водойми, антропогенний вплив, комплексний аналіз.

Formulation of the problem. Ecosystems of artificial lakes are under anthropogenic impact due to economic and recreational use. The consequence of this activity is the activation of the processes of eutrophication of water bodies. Anthropogenization leads to increased heating and eutrophication of lakes, causes their isolation and intensification of aging processes in water bodies. Therefore, there is an urgent need for comprehensive research and analysis of aspects of activities in urban agglomerations, which will make it possible to choose the most appropriate options for urban water management. Monitoring studies of surface water quality are based on taking into account the main functions of hydroecosystems and adjacent territories. The works of scientists V. Khilchevsky, S. Afanasyev, M. Yatsyuk, Ya.P. Didukh are devoted to the study of water bodies in places [1-4]. Based on the results of the inspection and analysis, it was noted that there are unresolved issues 
Yue Zheng, Sheviakina N.A., ...

in improving the methodology for monitoring and managing ecosystems, in particular, there is no infrastructure for operational monitoring of the dynamics of anthropogenic and renaturalization processes. There is no database of the state of ecosystems based on information technology. This does not allow the creation of clear ecological priorities for the development of a number of water systems. An important component of these studies is the analysis of the distribution of biotopes in the studied territory of the urbanized lake. There is a need for further in-depth studies of lakes, reservoirs, ponds, as reservoirs of delayed water exchange. It is necessary to study the dynamics of their existence, not only in interconnection, but also of the processes occurring in the coastal territories [5].

Relevance of research. The anthropogenic impact on lakes in urbanized conditions differs significantly in structure and intensity from traditional types of impact in natural areas, where the main factors are eutrophication and changes in the water regime, and a decrease in biodiversity due to uncontrolled fishing. But in cities, four sources of pollution of water bodies are leading: housing and communal services, automobile transport, industrial waste, and recreational activities. The approach to the study of lakes, reservoirs, ponds (as reservoirs of delayed water exchange) provides for the study of the dynamics of their existence not only in interconnection, but also the processes occurring in the catchment. Lakes in urban agglomerations contribute to the formation of a special microclimate. Hydrological features affect the specifics of the meteorological picture of the local water body and the area around it. The microclimate of the coastal area of the lake is influenced by many factors: the terrain, the size of the water body, the amount of pollutant emissions, the nature of pollution, the number of population.

Microclimate is a local feature of the surface layer climate. These features change significantly over short distances. In one geographic area with a general climate, different microclimate options are observed [6]. Over the forest and the neighboring meadow, near the lake and at a distance from it, the atmospheric conditions will differ to a greater or lesser extent. This can be especially observed in urban agglomerations with dense buildings. One of the factors influencing the formation of the microclimate of the territory is the distribution of the biotopes of this territory. Determination of the area of biotopes is necessary to determine informative signs of the ecological state of the territory and to determine the natural resource potential. The study of the structure of shallow biotopes is an informative indicator of the state of the lake ecosystem. Data on the distribution of overgrowth of coastal areas with vegetation groups, as well as urbanized water areas, are perfectly deciphered on satellite images. These results can be used to summarize information about the state of the ecosystem. Biotope change affects the microclimate of neighborhoods [7]. The use of space images makes it possible to analyze the quanti-
GEOINFORMATION TECHNOLOGIES...

tative indicators of the spatial structural units of a water body, predict the course of successive processes, assess the resource potential of hydroecosystems, identify possible threats to both biodiversity and water quality [8]. There is a large amount of work devoted to the use of Earth remote sensing methods for solving problems of nature management. First of all, these are the works of scientists: S.O.Dovgiy, Ya. Krasovsky, V.I. Doll, N.A. Popov, A.N. Trofymchuk, A.D. Fedorovskiy [9-11].

A satellite image is an independent reliable source of information and has the greatest effect in solving the following tasks: definition of the area and the territorial placement of objects; operative assessment of the state of nature-protected objects; creation of databases for species and landscape diversity inventory and effective environmental management; identification of the territory where the most adverse impact on the natural environment occurs; and identification of areas of conflict between different users.

The involvement $\mathrm{f}$ information technologies for the study of the limnological system, their morphology and components at the modern scientific and technical level is an important task for addressing the issues related to nature conservation and recreational and economic functions of the urbanized limnological system and adjoining territories [12-14].

Presentation of the main material. The article presents a study of one of the limnological objects of anthropogenic origin, namely Lake Verbne in the city of Kyiv. This lake was created in the 1960s as a classic hydrological quarry. The sand from this quarry was used in the construction of the Obolon residential area. Now Lake Verbne is a local nature conservation object an ichthyological reserve with an area of 31.8 hectares. The Lake Verbne is located in the northern part of the megalopolis of Kyiv (Figure 1).

The lake is located in the northern part of Kyiv, in the southeastern part of the Obolon residential area, between Moskovsky Prospekt, Priozernaya Street and Heroes of Stalingrad Avenue. The lake is probably a separated section of the former bed of the Pochayna River. Along its long-standing bed, there are now a number of lakes with the common name Opechen. The limnological system of Lake Verbne (Kyiv) was considered as an example of integrated application of remote sensing capabilities urbanized water bodies.

The northern shore of the lake is a gentle beach, the southern shore is raised above the level of the water surface by $1.0-1.5 \mathrm{~m}$. On the southern side, the lake was partially filled up during the construction of the microdistrict, so its area slightly decreased. The reservoir is low-flowing. The lake has an inflow of surface and ground water, the flow is carried out by filtering water in the lake bed. The lake is used as a water intake for surface and groundwater runoff. There are organized and unorganized beaches, active recreational fishing. Sources of water pollution are only surface runoff from the catchment area, industrial runoff is absent, as 
well as recreation. Morphometric characteristics are determined from bathymetric or hypsometric maps. The use of information and analytical technologies provides an assessment of the dynamics of morphometric characteristics and spatial distribution of such investigated integral hydroecological parameters as the shape and perimeter of the coastal strip [15]. With the help of echolocation technologies, the scientists of the Institute of Telecommunications and the Global Information Space of the National Academy of Sciences of Ukraine have built bathymetric maps of the water area of Lake Verbne [16]. According to the results of bathymetry, the maximum depth of the reservoir was specified, it is $14.8 \mathrm{~m}$. the central part increases from west to east in proportion to the increase in the width of the reservoir [17].

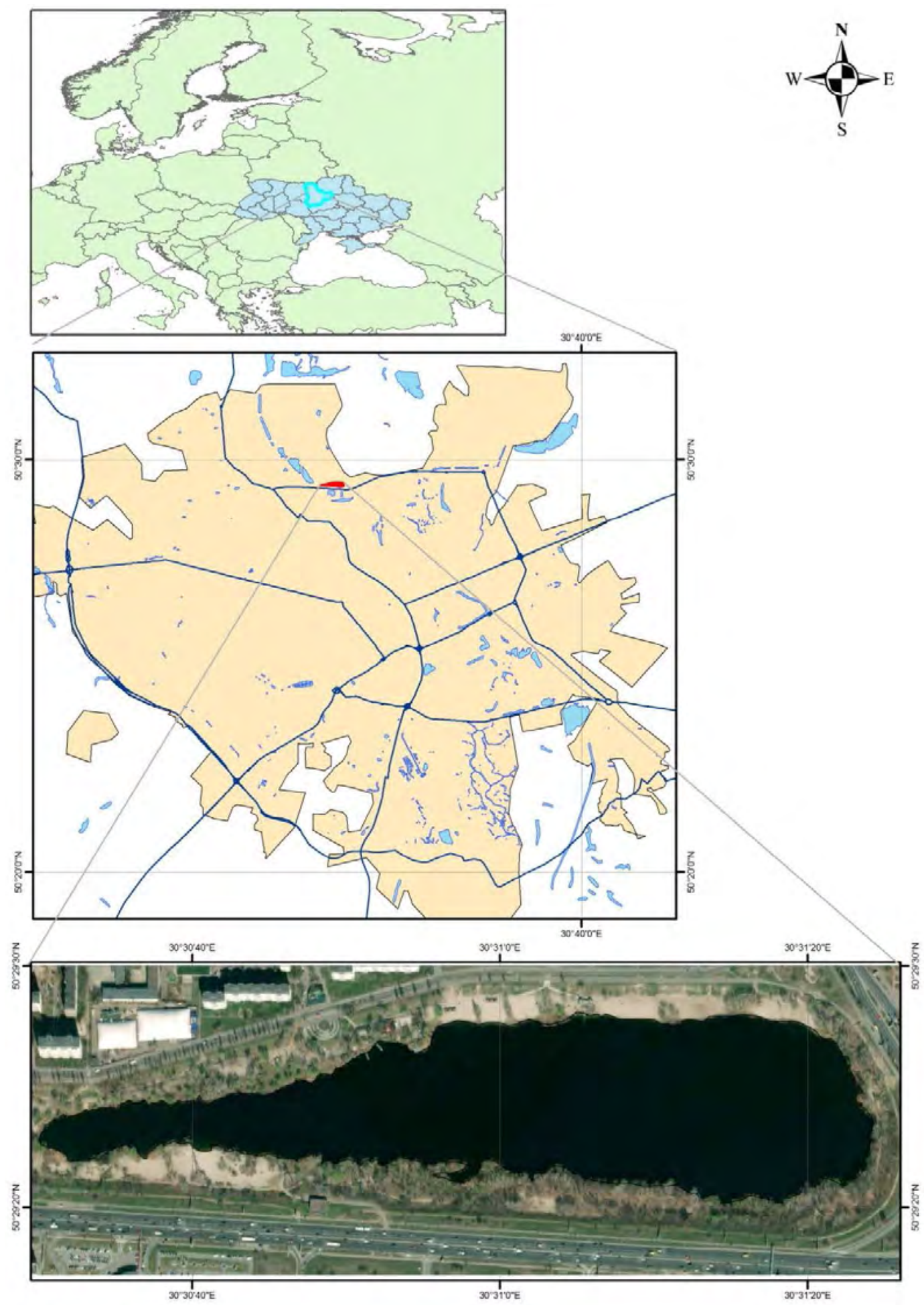

Figure 1. The limnological system of Lake Verbne (Kyiv) 


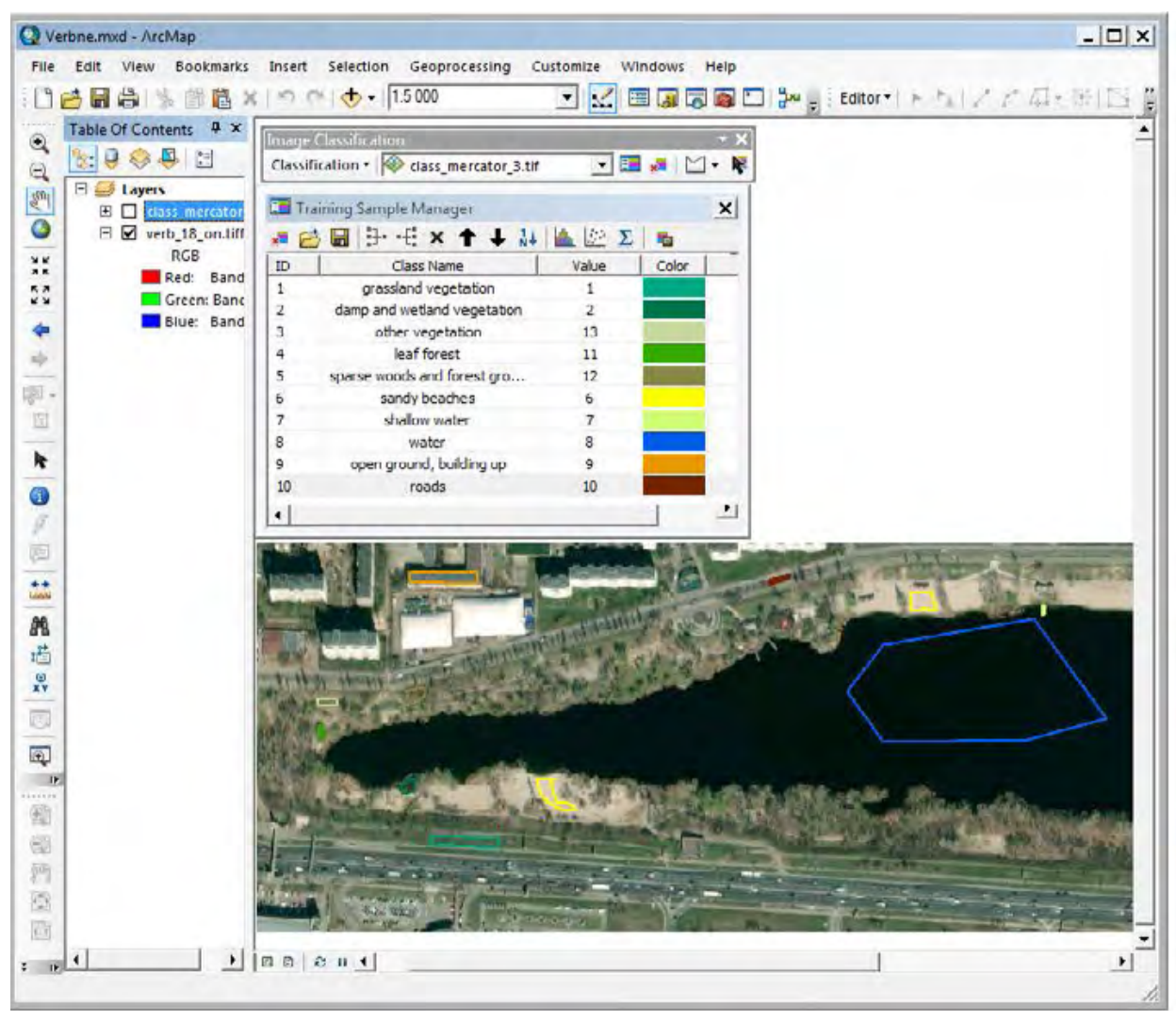

Figure 2. The pixel areas on the space image

The use of geoinformation technologies is considered from the point of view of a systematic approach, which includes: collection, processing and formalization of information about the state of the urbanized limnological system, accumulation and processing of data, their interpretation in graphic form on electronic maps.

Nowadays there are a lot of applicable software of different levels for remotely sensed data and images processing starting from distributing free to expensive highly professional ones. It allows implementing the wide spectrum of processing, visualization, analysis and use of geographical information. Erdas Imagine, ArcGis 10 and QGis software packages were used for processing and interpretation of remote sensing data. The packages are built according to module hierarchical principle and decision is scaled the efficiency of which depends on the users' requirements to images processing process [18]. The above software product tools were involved into the work with the satellite images during survey the Lake Verbne.

That satellite images processing process consists of identification of exposure period required for chosen area under survey, remotely sensed data selection with required resolution by means of software products statistic calculation - getting of analytical graph, accuracy validation of got values in comparison to the earth based results, generation of obtained information into geoinformation system with further ability to get necessary information as for the object under survey using GIS technical tools [19].
The algorithm for constructing a biotope map is as follows:

- selection of a satellite image;

- determination of standards for each of the classes (biotopes);

- viewing the spectral histograms of the selected classes;

- the implementation of the classification;

- obtaining the resulting raster, converting it into a vector and manual correction of erroneous objects;

- calculation of the areas of biotopes;

- raster generalization and smoothed presentation.

The data are analyzed in the ArcGIS software product, module Image Classification. Image classification is a powerful type of image analysis that uses machine learning to identify patterns and differences in land cover in drone, aerial, or satellite imagery. There are also tools for assessing accuracy by comparing the classified image to a reference image (esri.com/en-us/home, 2021). This module allows you to calculate and select areas according to the same criteria. Generation of criterion classes is done by expert method. The pixel areas on the space image are selected according to the criteria table.

First, a vector template file was built in the ArcGis program. In this file, at least 10 reference plots were allocated for each selected class of objects on the basis of a priori information about the geobotanical zoning of the territory and field studies [20]. The coverage was carried out over the entire spectral range of each class as much as possible (Figure 2). Further, a study was car- 


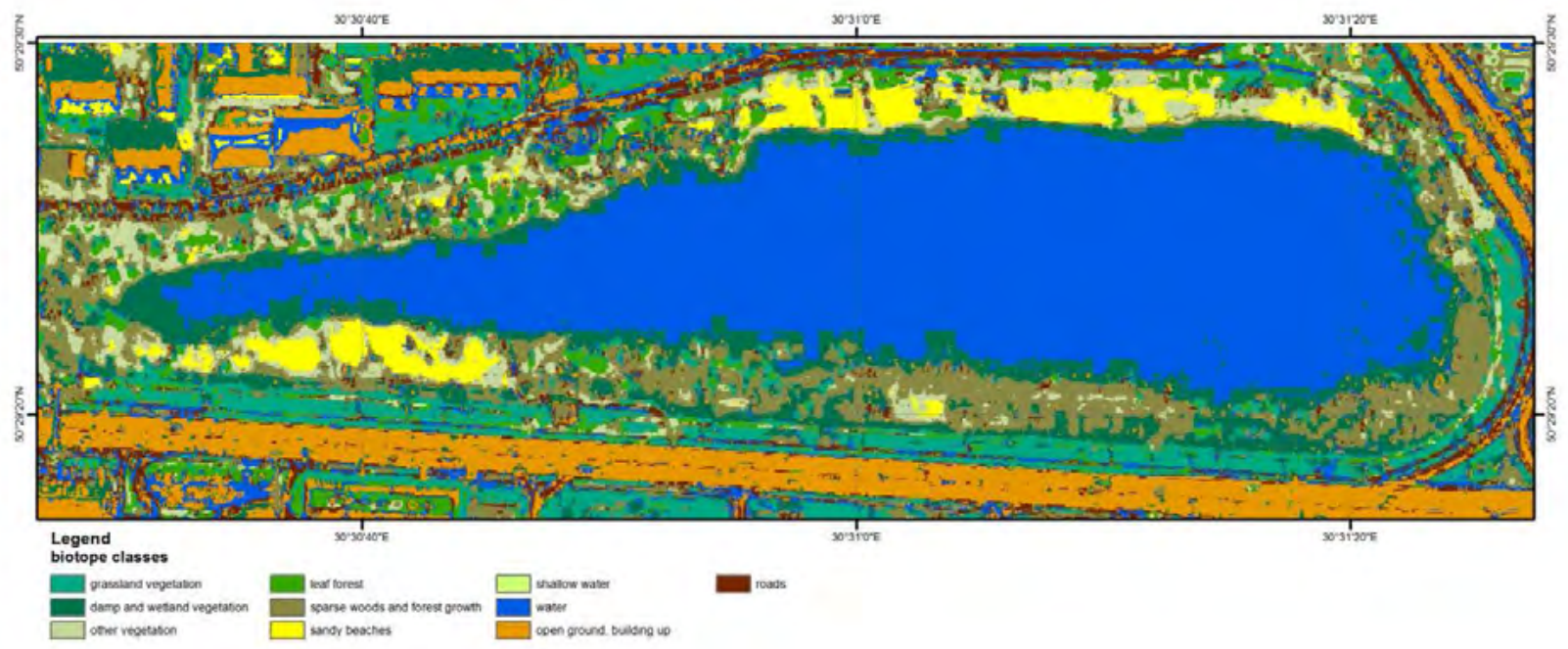

Figure 3. Classification of biotopes

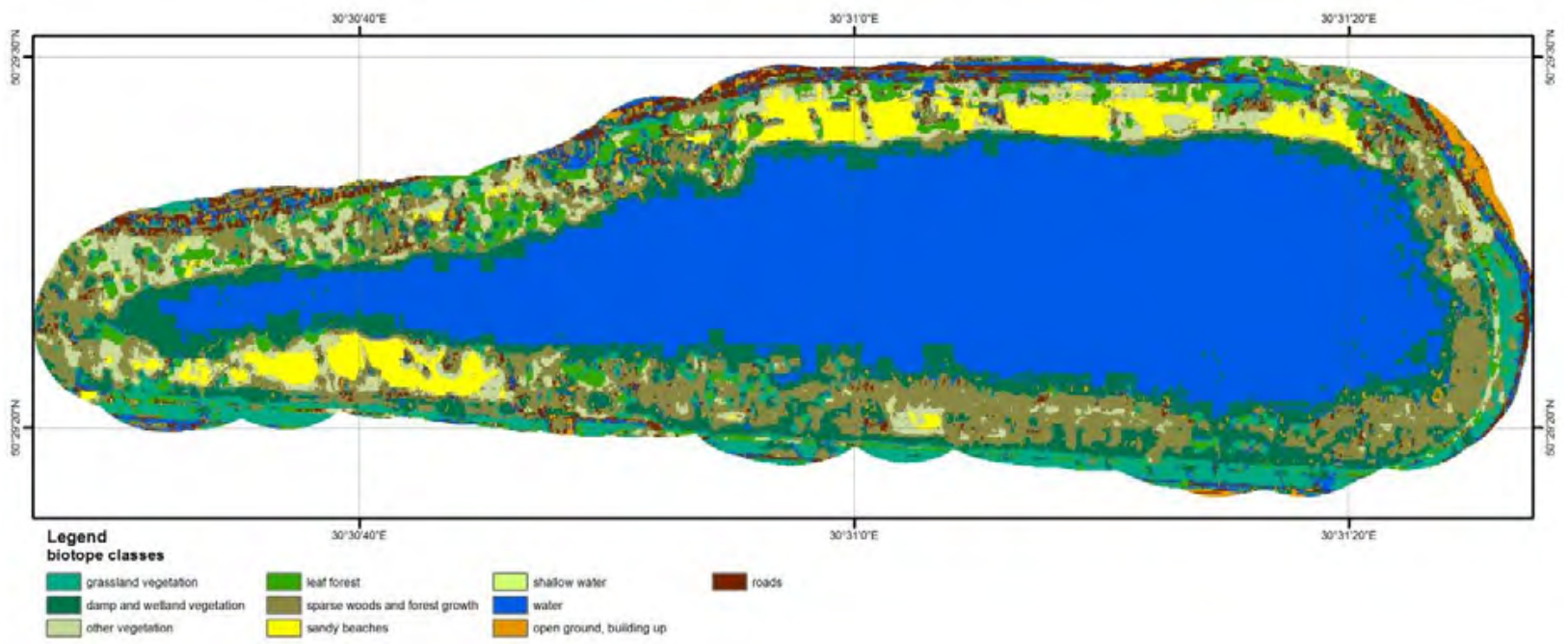

Figure 4. The lake area with a buffer zone of 100 meters

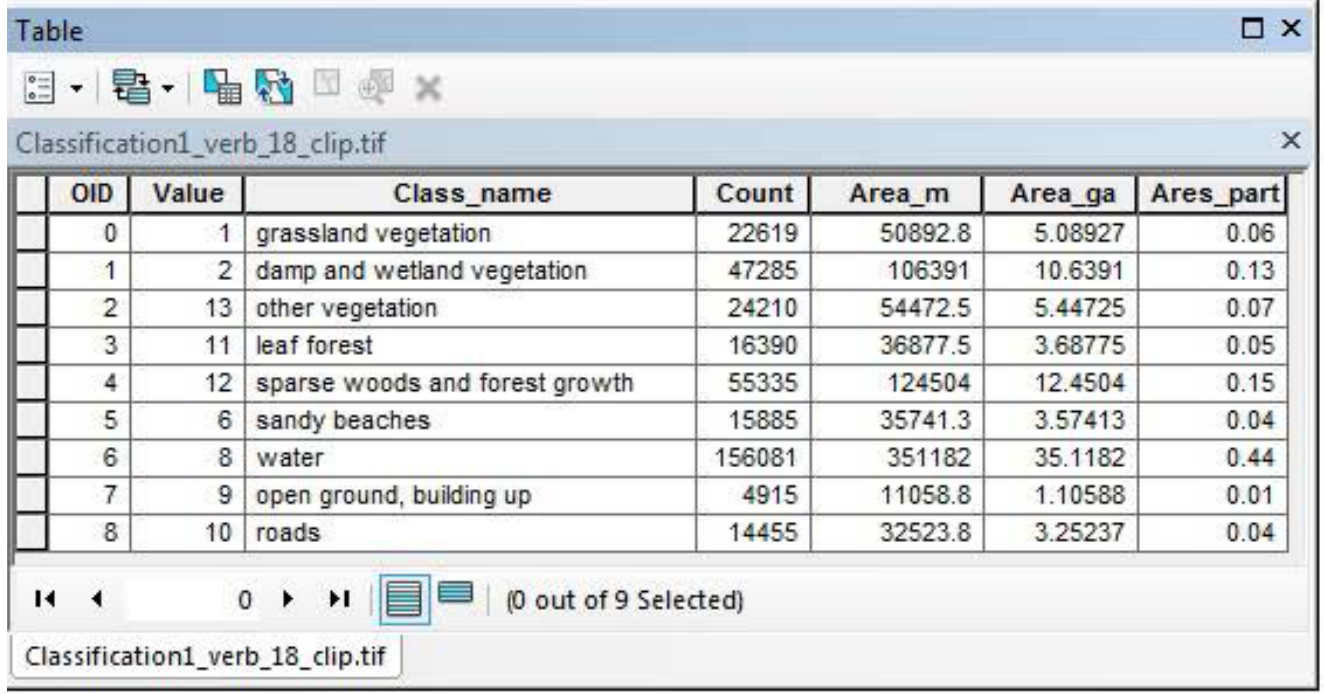

Figure 5. Calculating the area of biotopes 

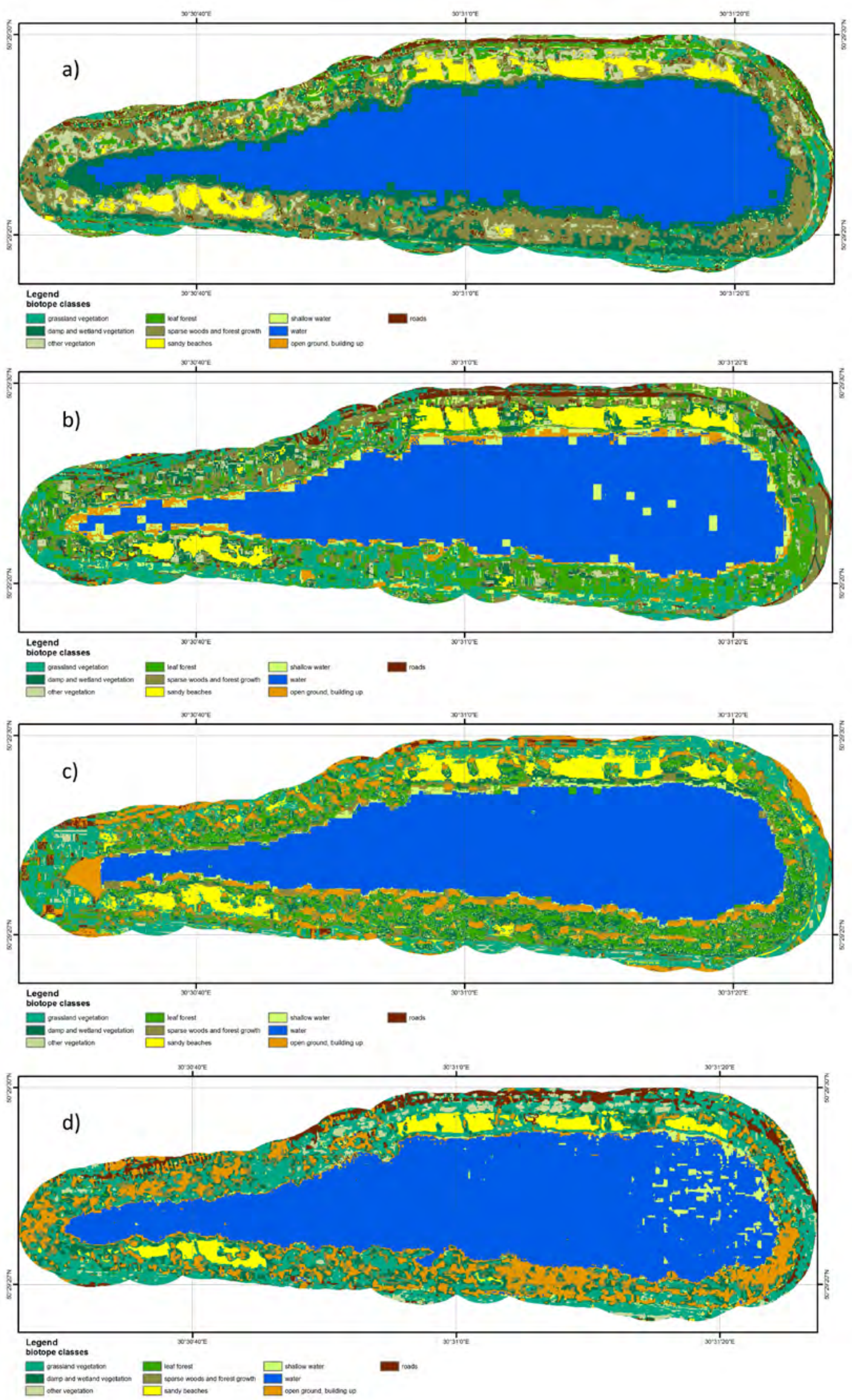

Figure 6. Classification of biotopes a) 2017, b) 2018, c) 2019, d) 2020 
Table 1

Biotope areas for different years in the study area

\begin{tabular}{|l|c|c|c|c|}
\hline \multirow{2}{*}{\multicolumn{1}{|c|}{ Class name }} & \multicolumn{4}{c|}{ Areas, ha } \\
\cline { 2 - 5 } & $\mathbf{2 0 1 7}$ & $\mathbf{2 0 1 8}$ & $\mathbf{2 0 1 9}$ & $\mathbf{2 0 2 0}$ \\
\hline grassland vegetation & 5.25024 & 10.36123 & 10.38082 & 14.79499 \\
\hline damp and wetland vegetation & 11.18808 & 4.984272 & 6.885072 & 6.97248 \\
\hline other vegetation & 5.138928 & 2.173392 & 0.846576 & 2.059632 \\
\hline leaf forest & 4.35672 & 9.78768 & 8.845632 & 0.12888 \\
\hline sparse woods and forest growth & 13.50245 & 7.416144 & 6.33096 & 2.796624 \\
\hline sandy beaches & 3.612672 & 3.699072 & 4.640112 & 2.847168 \\
\hline shallow water & 1.584144 & 3.978576 & 3.059568 & 1.805472 \\
\hline water & 33.36653 & 32.63774 & 32.04691 & 36.79114 \\
\hline open ground, building up & 0.004253 & 3.078288 & 6.820848 & 9.649152 \\
\hline roads & 2.844432 & 2.727792 & 0.987696 & 2.998656 \\
\hline
\end{tabular}

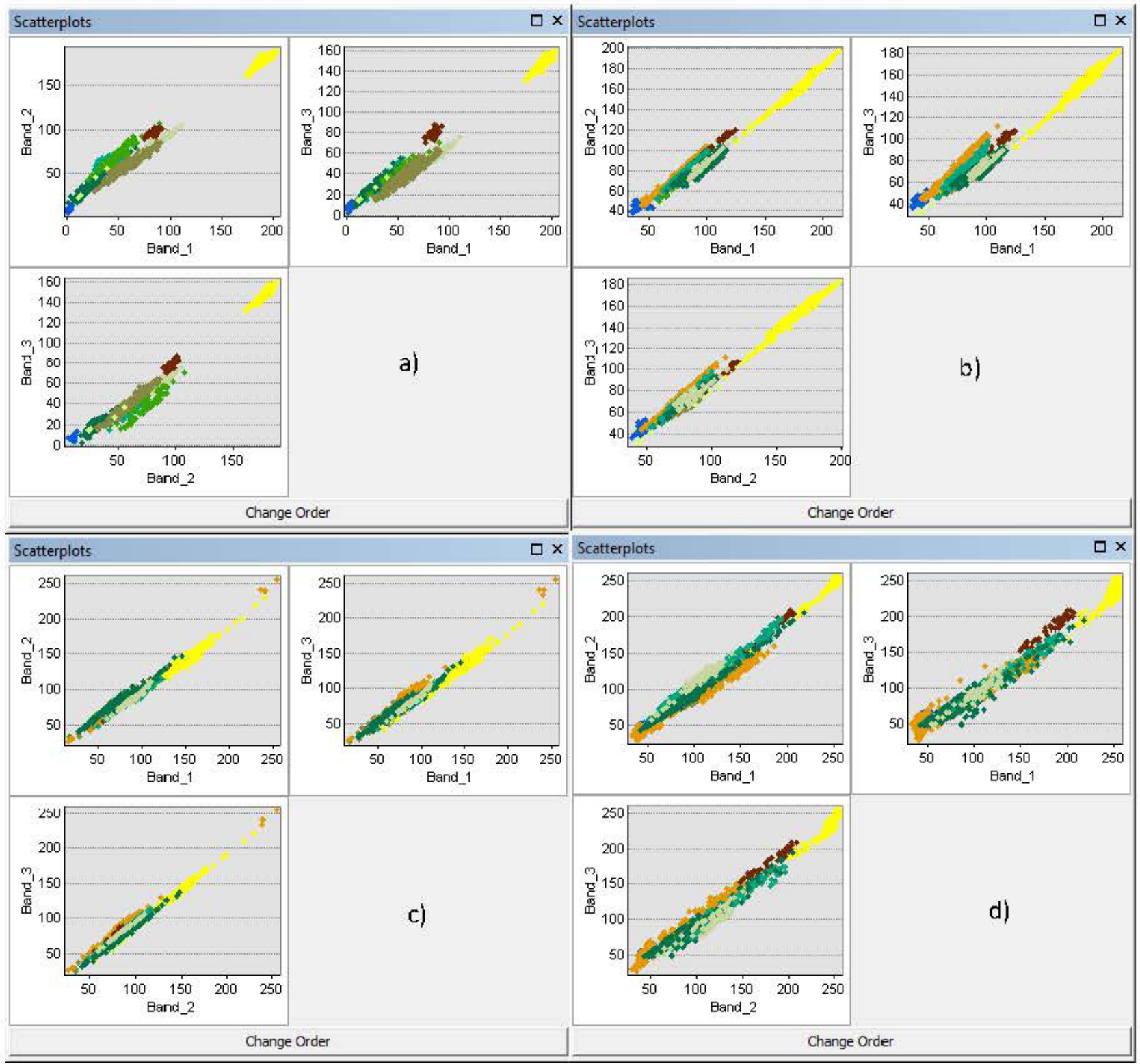

Figure 7. Relative change of the biotope area in the study area 
Yue Zheng, Sheviakina N.A., ...

ried out of the spectral brightness of reflecting surfaces of various types (classes) depending on the wavelength on the synthesized images.

As a result, on the territory of the limnological system of Lake Verbne (Kyiv) 10 main classes of reflective surfaces were selected: grassland vegetation groupings of medium-high helophytes with dead stems leaving for the winter; damp and wetland vegetation woody-shrub cenoses formed under conditions of excessive moisture; other vegetation - groups of shrubs that form under conditions of variable moisture mainly on silty and loamy soils; leaf forest - swamp willow groups (Salicion cinereae); sparse woods and forest growth; sandy beaches; shallow water - flooding zone and coastal belt, littoral of the floodplain and pool of the lake, occupied by groups dominated by tall-grass helophytes on sandy-silty and silty soils; water; open ground, building up; roads.

As a result of the classification, the final image was obtained, in which each pixel was assigned to one of the classes according to the spectral images of the standards. The module automatically selects all the pixels with the same criteria on the image. In result classification of biotopes on the space image is done (Figure 3).

For further calculations of the area of biotopes, a part of the water protection zone of the lake, one hundred meters wide, was included in the analysis. At the same time, the features of the anthropogenic impact on Lake Verbne, namely recreation, were taken into account. This one hundred meter zone should be a coastal protection strip along the lake. A stricter regime of economic activity is established in this territory than in the rest of the water protection zone, in accordance with Article 60 of the Land Code of Ukraine. Accordingly, on the satellite image, the area of the lake with a 100-meter protective strip was allocated for analysis (Figure 4). The area of the lake with an attached 100-meter zone is 80,36 ha. As a result, the areas of biotopes were calculated and the part in the total area of the lake was analyzed (Figure 5).

Using this technology on a series of images we get monitoring of biotope areas. The images were chosen approximately in the same time interval with the frequency of one year. Frequency of imaging the same place on the Earth's surface by high-resolution satellites is about 30-40 days. The pictures were taken in the late spring and early summer. Space images from the archives of the Institute of Telecommunications and Global Information Space at the National Academy of Sciences of Ukraine were used for periods 2017-2020.

Classification maps of biotopes in the spring and summer period were obtained for four years. Data on changes in the area of the biot-

\section{GEOINFORMATION TECHNOLOGIES...}

ope class were obtained (Figure 6). A precision analysis of the definition of biotope classes was performed. As a result of the analysis of the data obtained, an assessment of changes in the distribution of biotopes was carried out. So, as of 2020 , the water surface of the lake remained practically unchanged compared to 2017 (Table 1). The water surface area is almost unchanged. Less than $4 \%$ of the total area.

But there are changes in the areas «leaf forest» and «sparse woods and forest growth», the area of these biotopes decreased by $5 \%$ and $13 \%$, respectively. And also we observe change «grassland vegetation», the area of this biotope has increased over the comparative period by $12 \%$. Therefore, an increase in the area of one biotope leads to a decrease in the area of another biotope (Figure 7). That is, we observe a gradual replacement of one biocenosis with another, which indicates a successional process in the study area. These changes occur primarily under the influence of the recreational load, namely the trampling of vegetation by local residents and vacationers, the uncontrolled arrangement of picnic areas, recreation and swimming areas.

Along with the anthropogenic impact, it is necessary to take into account global climatic changes. Climatic changes form the microclimate of urbanized territories, including natural biotopes of urbanized lake ecosystems, which are the most vulnerable. They need special protection and development of conservation measures. This approach is important today in the implementation of environmental monitoring, in the creation and improvement of the system of protected objects, ensuring measures for their protection.

The investigated area has a significant natural resource potential for recreational purposes. The lake has a well-maintained beach for swimming and relaxation. The beach area was allocated a separate class in space images. In order to study the dynamics of changes in the specified biotope, the area of the beach was calculated. As a result, the constancy of the ecosys-

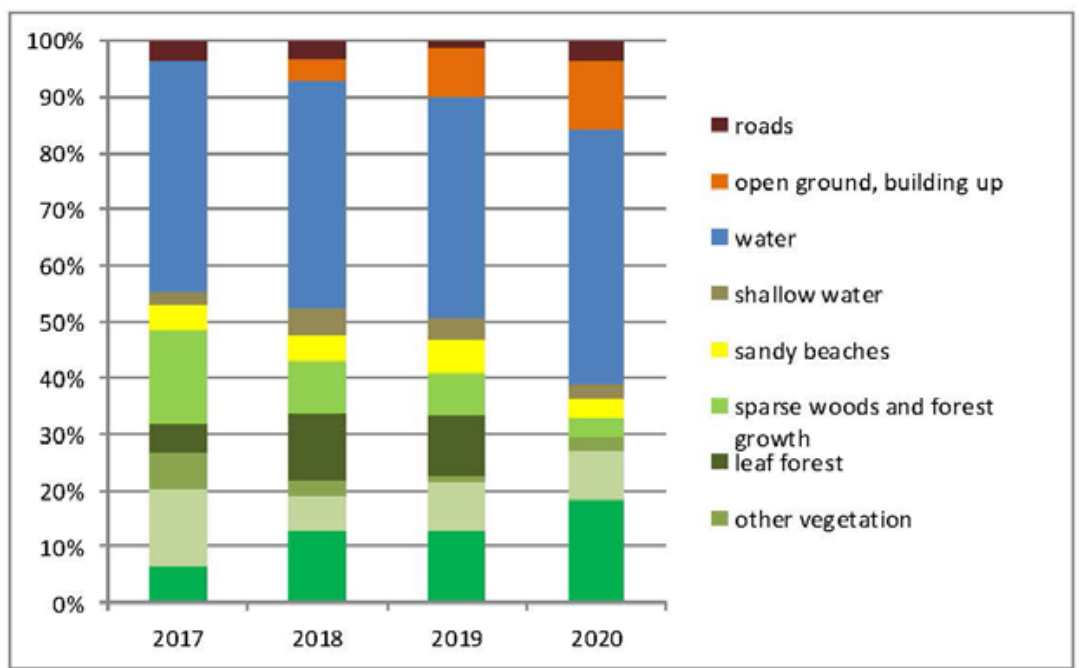

Figure 8. Analysis of biotope class selection: a) 2017 , b) 2018 , c) 2019 , d) 2020 
tem of the specified biotope was determined. The area of beaches varies within 1.7\% (Figure 7).

In order to establish the relationship between environmental factors and the distribution of biotopes, correlation analysis was used (Figure 8). We observe the area of beaches varies within $1.7 \%$, however, the accuracy of selection among other biotopes is the highest.

We can note that the recreational load on the coastal area of the lake is increasing due to direct anthropogenic impact. In areas with vegetation, you can determine the mass concentration of vacationers. As a result of trampling, degradation of plant complexes is noted until the complete disappearance of macrophyte groups [18]. Therefore, it is necessary to conduct further research, monitoring the quality of the recreational potential on the territory of Lake Verbne. This is necessary to regulate unauthorized recreational development of the territory: filling the coastal strip of lakes with sand (primarily the lakeside floodplain and depressions) to create beaches with complete destruction of vegetation.

So, the results of the presented study show the effectiveness of Earth remote sensing methods for monitoring studies on the distribution of biotopes, determining the ecological state and quality of the recreational potential of urbanized water bodies in cities. Remote geoecological monitoring studies make it possible to carry out a reliable assessment of the state of ecosystems and predict their further changes, however, it requires long-term data and complex labor-intensive work on the analysis and processing of these data.

\section{Main conclusions.}

As a result of the study, remote sensing data were processed at different times, an analysis of changes in the area of biotopes of Lake Verbne (Kyiv), which occurred over a period of time, namely 2017-2020. The results of habitat change and the state of the coastal area were obtained. The coastal territory of the lake, the formed lake basin are estimated, the limits of fluctuations of water level are established. In general, the studied limnoecosystem is stable with gradual succession changes.

It is important to note that the coastal area of the lake is increasing recreational load due to direct anthropogenic impact. In areas with vegetation there is a mass accumulation of vacationers. As a result of trampling, degradation of plant complexes is observed. The results of the presented study show the effectiveness of remote sensing methods for monitoring the distribution of habitats, determining the ecological status and quality of recreational potential of urban water bodies of cities.

The presented researches are necessary for stabilization of ecological balance of urban agglomerations, increase of productivity of urban landscapes, improvement of a condition of environment and maintenance of ecological safety of the urbanized coastal territories and lakes.

\section{Bibliography}

1. Моніторинг та охорона біорізноманіття в Україні. Прикладні аспекти моніторингу та охорони біорізноманіття Серія: «Conservation Biology in Ukraine». Вип. 16. Т. 3. Київ, Чернівці: Друк Арт, 2020. 528 с.

2. Хільчевський В.К., Ободовський О.Г., Гребінь В.В. та ін. Загальна гідрологія: підручник. Київ: Видавничо-поліграфічний центр «Київський університет», 2008. 399 с.

3. Класифікація рослинності та біотопів України: матеріали третьої науково-теоретичної конференції. За заг. ред. Я.П. Дідуха, Д.В. Дубини. Київ, 2018. 188 с.

4. Дідух Я. П., Вакаренко Л. П.. Кадастр біотопів як основа збереження Землі при ринкових відносинах. Вісник НАН Украӥни. 2019. № 9. С. 70-80.

5. Trofymchuk O., Kreta D., Myrontsov M., Okhariev V., Shumeiko V., Zagorodnia S. Information Technology in Environmental Monitoring for Territorial System Ecological Assessment. J. Environ. Sci. and Engineering, 2015. P. 79-84.

6. The Global Risks Report 2018, 13th Edition.World Economic Forum. Geneva, 2018. 80 p.

7. Федоровський О. Д., Зуб Л. М., Дьяченко Т. М., Томченко О. В., Хижняк А. В., Якимчук В. Г. Дистанційне оцінювання екологічного стану водойм на основі багатомірної щільності розподілу площ біотопів на прикладі Київського водосховища. Космічна наука і технологія. 2020. Т. 26, № 5 (126). С. 38-47.

8. Томченко О.В., Соколовская А.В., Федоровский А.Д. Моделирование экологического состояния антропогенных ландшафтов на основе космического геомониторинга. Геоінформатика. 2015. № 1. С. 77-84.

9. Довгий С. О., Бідюк П. І., Трофимчук О. М., Савенков О. І. Методи прогнозування в системах підтримки прийняття рішень. Київ: Азимут-Україна, 2011. 608 с.

10. Гончар А.І. Концепція розвитку гідроакустики в Україні. Гідроакустичний журнал. Запоріжжя: НТЦ ПАС НАН України. 2006. № 3. C. 5-16.

11. Arkhipov A. I., Glazunov N. M., Khyzhniak À. V. Heuristic Criterion for Class Recognition by Spectral Brightness. Cybernetics and Systems Analysis. 2018. Vol. 54, № 1. P. 94-98.

12. Томченко О.В. Обгрунтування методів системного аналізу стану водноболотних угідь з використанням даних дистанційного зондування Землі і наземних спостережень (на прикладі верхів'я Київського водосховища): автореферат дис. ... канд. технічних наук, спец. 05.07.12: Науковий центр аерокосмічних досліджень Землі НАН України. Київ, 2015. 22 с.

13. Радчук І.В. Екологічний моніторинг лімнологічних систем методами дистанційного зондування Землі : автореф. дис. ... канд. техн. наук, спец. 21.06.01: Нац. ун-т буд-ва і архітектури. Київ, 2015. 19 с.

14. Загородня С.А. Оцінка екологічного стану природно - заповідних територій засобами геоінформаційних технологій : автореф. дис. ... канд. техн. наук, спец. 21.06.01: Нац. ун-т буд-ва і архітектури. Київ, 2016. 22 с.

15. Трофимчук О.М., Мокрий В.І., Радчук В.В., Радчук І.В., Загородня С.А. Інформаційне забезпечення гідроакустичного моніторингу озер Західного Полісся. Екологічна безпека та природокористування. 2015. Вип. 1(17). С. 5-15. 
16. Trofymchuk O., Klymenko V., Sheviakina N., Zahorodnya S., Radchuk I. Assessment of the impact of anthropogenic activities on aquatic ecosystems. Water Supply and Wastewater Disposal, Designing, Construction, Operation and Monitoring: Monograph. Lublin. 2020. P. 328-335.

17. Trofymchuk O., Klymenko V., Anpilova Y., Sheviakina N., Zagorodnia S. The aspects of using GIS in monitoring of environmental components. International multidisciplinary scientific geoconference, SGEM; Sofia. Vol. 20, Iss. 2.1. Albena. Bulgaria. 2020. P. 581.

18. Trofymchuk O., Zahorodnya S., Sheviakina N., Radchuk I., Tomchenko O. Remote Sensing Monitoring of Biotopes Distribution within Nature Reserve Area. Journal of Environmental Research, Engineering and Management. 2020. Vol. 76, No 3. P. $109-120$.

19. Томченко О.В., Манько Д.І. Супутниковий моніторинг скупчень планктонних водоростей («цвітіння» води). Тези доповідей III науково-практичної конференції «Аерокосмічні технології в Україні: проблеми та перспективи» (Новосілки, 12-13 вересня 2019 р.). Київ, 2019. С. 86-87.

20. Protasov A.A., Barinova S.S., Novoselova T.N., Buseva Zh.F., Tomchenko O.V., Sylaieva A.A., Lubskiy N.S., Semenchenko V.P., Sysova E.A. The heterogeneity of the abiotic and biotic components of techno-ecosystems: view from space and from the Earth. European Scientific Journal. Jan. 2019 edition Vol. 15, No 3. P. 423-448. 